Article

\title{
Decrease of the Maximum Speed in Highway Tunnels as a Measure to Foster Energy Savings and Sustainability
}

\author{
Antonio Peña-García ${ }^{1, *}$, Ferdinando Salata ${ }^{2}$ (D) and Iacopo Golasi ${ }^{2}$ (D) \\ 1 Department of Civil Engineering \& Research Group "Lighting Technology for Safety and Sustainability", \\ University of Granada, 18071 Granada, Spain \\ 2 DIAEE-Area FisicaTecnica, UniversitàdegliStudi di Roma “Sapienza”, 00184 Roma, Italy; \\ ferdinando.salata@uniroma1.it (F.S.); iacopo.golasi@uniroma1.it (I.G.) \\ * Correspondence: pgarcia@ugr.es; Tel.: +34-958-249-435
}

Received: 6 February 2019; Accepted: 15 February 2019; Published: 20 February 2019

check for updates

\begin{abstract}
The high energy consumption of the lighting installations in highway tunnels has become a hot topic in the last few years due to the high figures in terms of money, consumed energy, use of raw materials, emissions of greenhouse gases due to the remarkable number of manufactured elements, and maintenance, among others. In spite of the different strategies proposed up to date and their savings, the potential benefits of decreasing the maximum speed allowed in tunnels have not been considered in depth as a complementary measure yet. In this work, the impact of such a decrease in terms of energy consumption, number projectors, carbon dioxide $\left(\mathrm{CO}_{2}\right)$ emissions, and yearly costs in energy is analyzed and discussed. The results strongly suggest the convenience of introducing maximum speed reduction in traffic regulations which, in addition, could create positive synergies with traffic safety.
\end{abstract}

Keywords: lighting; energy savings; tunnels; environmental impact; road safety; $\mathrm{CO}_{2}$ emissions

\section{Introduction}

The causes of the high lighting requirements in road tunnels have been known for decades. Thus, the slow adaptation of the human visual system when going from very bright to darker environments is the main factor for such high demands [1]. This can easily be proven by the daily fact that we stay blind for many seconds after suddenly closing the windows on a sunny day. Even after these few seconds, when we start to distinguish the features of the room in shadows, we do not achieve our maximum visual performance in poorly illuminated environments until about 35 minutes have gone by. When this daily situation is exported to driving, the consequences can be really dramatic: One driver travelling at $100 \mathrm{~km} / \mathrm{h}$ cannot withstand the slightest impairment in visual performance, because a loss of vision of just one second means $28 \mathrm{~m}$ of uncontrolled advance.

Due to this situation, the lighting installation of road tunnels must provide very high amounts of luminous flux during daytime, especially on sunny days. This causes really remarkable consumptions in energy and also high demands in the number of projectors, wiring, maintenance, etc. These lighting levels are quantified as luminance (emitted luminous flux per unit of surface, solid angle in one given direction) of roads and walls.

For this reason, researchers and public administrations are putting more and more efforts into achieving sustainable tunnel lighting installations not impairing driver safety.

Some strategies proposed up to date involve the use of natural light. Among them, some are based on the introduction of natural light inside the tunnels [2-4], which is proven to also be effective 
in buildings and other indoor facilities [5-9]. Other strategies to profit from sunlight have been carried out by shifting out the first meters of the tunnel [10-20]. In spite of their utility and promising future, the strategies to use natural light in tunnels are being implemented slowly because they require initial investment that, in many cases, lead to administrative reluctance.

The present study is focused on a second set of strategies to improve tunnel sustainability. These strategies do not pretend to take the requested luminous flux from the sun but reduce the flux requirements themselves.

They deal with actions on its portal surroundings, pavements, type of installed projectors and, as presented in this work, with the maximum allowed speed. They are briefly described:

1. Coverage of the portal surroundings with low reflectance elements like vegetal species [21,22] or low reflectance paint.

2. Use of high reflectance materials for the pavements: This way, most of the luminous flux reaching the pavement as illuminance will be reflected as luminance. Thus, the needed luminous flux per unit of surface and solid angle will reach the driver eye with a lower luminous flux emitted by the projectors. Some interesting works involving higher reflectance and even considerations on the life-cycle of the asphalts (a need towards a really circular economy) have been published lately [23-25].

3. Change from the classical high-pressure sodium lamps in projectors to LED to allow the regulation of luminous flux according to the different circumstances with the consequent energy savings [26,27].

The combination of all these strategies together to reduce energy consumption, number of projectors, and $\mathrm{CO}_{2}$ emissions has already been proposed [28], but in addition, and fully compatible with the strategies above, decreasing the maximum speed allowed inside the tunnels is a worthy measure to decrease energy and projector demands. The main reasons supporting this hypothesis are three:

(1) The coefficient " $\mathrm{k}$ ", relating the natural luminance in the driver's eye within a $20^{\circ}$ cone before the portal gate (called L20 luminance), and the luminance actually needed in the threshold zone, $\mathrm{L}_{\mathrm{th}}$ (luminous flux reflected by pavement and walls per unit of surface and solid angle in one given direction in the first hundred meters of the tunnel) is remarkably lower at minor speeds, as shown in Table 1 [1]. This makes the visual needs lower in terms of the luminous flux reaching the drivers' eyes.

(2) The decrease in maximum speed results in a shorter safety distance (SD). In addition to its implications in terms of safety, this distance determines the length of the threshold zone, which is the most demanding one in terms of luminance $\left(\mathrm{L}_{\mathrm{th}}\right)$ and, hence, number of installed projectors, with energy consumptions around $50 \%$ of the whole tunnel. In addition, the transition zone of the tunnels, whose length is the distance travelled at maximum speed in $20 \mathrm{~s}$, also decreases with lower maximum speed. Thus, the shorter the threshold and transition zones, the lower number of projectors, wiring, and maintenance needed.

(3) The decrease of SD allows smaller L20 cones. It means that the percentage of sky in such cones, if any, will decrease.

Beyond the arguments above, the increasing volumes of passenger and freight flows [29-33] highlight the importance of research and efforts to keep lighting levels as high as needed for safe transport but decreasing the impact on environmental and financial sustainability of tunnels and all kind of infrastructures. This way, the higher emission of greenhouse gases can be somewhat decreased whilst a higher number of road users benefits from it.

In this work, the results of reducing the allowed maximum speed in highway tunnels based on the hypothesis above as a complementary strategy to all those classically studied is presented and analyzed.

\section{Materials and Methods}

Although there are several regulatory frameworks in different nations, each with its own parameters, the calculations supporting the proposal of this research follow the methodology of CIE 
Publication 88:2004 [1], which is the international reference document in tunnel lighting. According to this standard, road tunnels are divided into five main zones when considered from the perspective of their lighting requirements. In the following paragraphs, these zones are described according to the relevant literature $[1,10,34]$ :

(1) Access zone: It is the opencast sky zone before the portal gate. Its length is the safety distance, $\mathrm{SD}$, which is given by:

$$
S D=v t_{0}+\frac{v^{2}}{2 g(f \pm s)}
$$

where $v$ is the vehicle speed in $\mathrm{m} / \mathrm{s}, t_{0}$ is the reaction time (considered as $1 \mathrm{~s}$ by CIE and $2 \mathrm{~s}$ in some national regulations like the Spanish [34]), $g$ is the acceleration of gravity, $f$ the friction coefficient, which depends on the atmospheric conditions (dry or wet road), and $s$ the tangent of the road slope in degrees (positive for slopes up and negative for slopes down).

(2) Threshold zone: It is extended from the gate towards the interior of the tunnel with a length equal to SD. The luminance in the first middle of the threshold zone, $\mathrm{L}_{\mathrm{th}}$, remains constant, whereas in the second middle of this zone, it decreases up to $40 \%$. It is the most energy-consuming zone in the whole tunnel.

(3) Transition zone: It follows the threshold one. Its length is given by the space gone down in $20 \mathrm{~s}$ by one vehicle at the maximum speed allowed in the tunnel. The luminance level in this zone, $\mathrm{L}_{\mathrm{tr}}$, progressively decreases to allow visual adaptation to the lighting conditions in the interior zone.

(4) Interior zone: From the end of the transition zone up to the exit zone. The luminance in this zone, $\mathrm{L}_{\mathrm{in}}$, remains constant, and it is the lowest in the whole tunnel.

(5) Exit zone: It is the last zone inside the tunnel, and the influence of the exterior lighting is important.

The luminance requirements in the most energy-consuming zones (threshold and transition) depend on the portal surroundings, tunnel orientation, and maximum speed allowed in the tunnel. These requirements are calculated departing from the luminance due to daylight in the eye of one driver approaching the tunnel at SD from the portal gate within a $20^{\circ}$ cone. It is called L20 luminance, and the methodology to calculate it is established by CIE. This methodology is based on the projection of one cone basis on the portal gate of the tunnel under consideration, as shown in Figure 1.

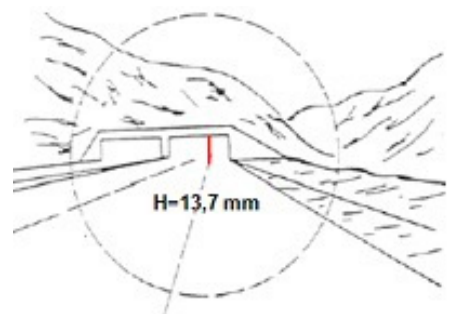

(a)

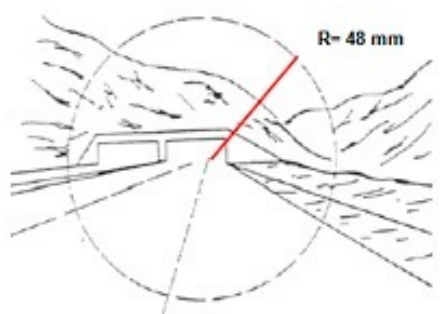

(b)

Figure 1. Basis of the L20 cone (a) and its radius (b) on a picture of the portal gate under a not very high mountain (adapted from Reference $[1,35]$ ).

Once the basis of the cone is established, the percentage of each element with characteristic luminance (sky, road, meadow, building, etc.) inside the basis is calculated. Departing from these percentages and the typical luminance of these elements established by the different standards, the L20 luminance is calculated according to the following formula:

$$
\begin{gathered}
L 20 \approx \gamma L_{S}+\rho L_{R}+m L_{M}+b L_{B} \\
\gamma+\rho+m+b=1(100 \%)
\end{gathered}
$$


In Equation (2), $\mathrm{L}_{S}, \mathrm{~L}_{\mathrm{R}}, \mathrm{L}_{\mathrm{M}}$, and $\mathrm{L}_{\mathrm{B}}$ are the values of sky, road, surrounding meadow, and surrounding building luminances, respectively, as established by the relevant standard or regulation (Reference [1] in this case). The coefficients $\gamma, \rho, \mathrm{m}$, and $\mathrm{b}$ are the percentages of sky, road, meadow, and building, respectively, contributing to L20.

Departing from the $\mathrm{L} 20$ luminance calculated, the luminance in the threshold zone, $\mathrm{L}_{\text {th }}$, is given by Equation (3):

$$
L_{t h}=k L 20 .
$$

The values of $\mathrm{k}$ as a function of $v_{\max }$ are shown in Table 1 [1].

Table 1. $k$ coefficient relating the luminance needed in the threshold $\left(\mathrm{L}_{\mathrm{th}}\right)$ with the L20 luminance (From CIE 88:2004, 2004, [1]).

\begin{tabular}{cc}
\hline $\boldsymbol{v}(\mathbf{k m} / \mathbf{h})$ & $\boldsymbol{k}$ \\
\hline$<60$ & 0.05 \\
80 & 0.06 \\
120 & 0.10 \\
\hline
\end{tabular}

The luminance required in the following zones of the tunnel is shown in Table 2 [1].

Table 2. Luminance requirements in the different zones of the road tunnel.

\begin{tabular}{|c|c|c|}
\hline Zone & & Luminance \\
\hline \multirow{2}{*}{ Threshold } & 1st half & $\mathrm{L}_{\mathrm{th}}$ \\
\hline & 2nd half & Progressive decrease to $0.4 \mathrm{~L}_{\mathrm{th}}$ \\
\hline Transition & & Progressive decrease to $0.14 \mathrm{~L}_{\mathrm{th}}$ \\
\hline Interior & & $\mathrm{L}_{\mathrm{in}}: 1-10\left(\mathrm{~cd} / \mathrm{m}^{2}\right)$ \\
\hline Exit & & Progressive increase to $5 \mathrm{~L}_{\mathrm{in}}$ \\
\hline
\end{tabular}

As shown in Tables 1 and 2, the higher the speed, the higher the $\mathrm{L}_{\text {th }}$ and, hence, the lighting requirements, consumed energy, number of projectors needed, and $\mathrm{CO}_{2}$ emissions in the threshold and transition zones.

The model tunnel under consideration will be one "geometrically and optically long" tunnel, incorporating all the zones described above, where some basic measures for energy savings (forestation of portal surroundings, change from high-pressure sodium (HPS) to LED and pavement with higher reflectance) have been implemented. It is located in the South-East of Spain with an East-West orientation. Given that this work deals with the effects of reducing the maximum speed and this parameter has an impact on the threshold and transition zones (that consume most of the tunnels resources), the results of this work were applied only to these zones. Thus, the comparison between the threshold and transition zones before and after actions implementation for daytime conditions will show the effect of such actions more accurately.

The evaluation of the $\mathrm{CO}_{2}$ emissions related with energy saving was carried out according to the data supplied by the Spanish National Commission on Markets and Competition (CNMC).

Finally, as highlighted at the beginning of this section, although the model tunnel is located in Spain, the parameters of the relevant CIE standard [1] were considered instead of the Spanish National Regulation on tunnel lighting [28]. Although they are rather different in some respects, the research focus of this article makes this more general framework more convenient.

\section{Results}

Before presenting the results of the proposed reduction in maximum speed on a real tunnel, there is one consideration not reported up to date about the impact of this reduction on the L20 value: The relationship 
between the radius of the L20 cone basis (which determines what elements of the tunnel surroundings are considered for L20 calculation) and the safety distance, SD, is given by Equation (4) [35]:

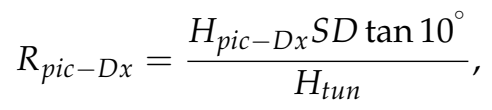

where $R_{\text {pic-Dx }}$ is the radius of the L20 cone basis in one picture taken from an unknown distance Dx. $H_{\text {pic-Dx }}$ is the height of the tunnel portal in one picture taken from an unknown distance Dx. $H_{t u n}$ is the real height of the tunnel portal.

Since SD and $v_{\max }$ are directly related by Equation (1), Equation (4) clearly shows that the lower the $v_{\max }$, the smaller the L20 cone basis. As shown in Figure 1, a small basis can avoid the sky contribution of tunnels under not very high mountains.

After this demonstration, the calculated results from the application of these measures to the model tunnel are presented. In this tunnel, before the introduction of any strategy to increase its sustainability after it started to work, the main parameters of the lighting installation with regard to energy, cost, and environmental impact are shown in Table 3:

Table 3. Main parameters of lighting installation before implementation of any action to increase its sustainability.

\begin{tabular}{ccccccc}
\hline & $\begin{array}{c}\text { Luminance } \\
\left(\mathbf{c d} / \mathbf{m}^{2}\right)\end{array}$ & $\begin{array}{c}\text { Length } \\
\mathbf{( m )}\end{array}$ & $\begin{array}{c}\text { Nr. HPS } \\
\text { Projectors }\end{array}$ & $\begin{array}{c}\text { Yearly cons. } \\
\mathbf{M W h}\end{array}$ & $\begin{array}{c}\text { Yearly CO } \mathbf{C O}_{2} \\
\text { Emissions } \\
\mathbf{( t n )}\end{array}$ & $\begin{array}{c}\text { Yearly Costs } \\
\mathbf{( € )}\end{array}$ \\
\hline $\begin{array}{c}\text { Threshold } \\
\text { zone-1 } \\
\text { Threshold } \\
\text { zone-2 } \\
\text { Threshold } \\
\text { zone-3 }\end{array}$ & 333.4 & 79.5 & 94 & 138.6 & 43.0 & 11,504 \\
$\begin{array}{c}\text { Transition } \\
\text { zone-1 }\end{array}$ & 283.4 & 39.8 & 40 & 59.0 & 18.3 & 4897 \\
$\begin{array}{c}\text { Transition } \\
\text { zone-3 }\end{array}$ & 133.4 & 184.7 & 154 & 128.8 & 39.9 & 4034 \\
$\begin{array}{c}\text { Transition } \\
\text { zone-3 }\end{array}$ & 100.0 & 184.7 & 116 & 96.6 & 29.9 & 8018 \\
Total & 66.7 & 184.7 & 78 & 64.4 & 20.0 & 5345 \\
\hline
\end{tabular}

It is necessary to remark that the calculations above have been carried with the parameters of typical installations in typical tunnels. They are the following:

- Pavement reflectance: $\rho=0.25$

- Light source in projectors: High-pressure sodium (HPS). Two different commercial lamps were considered for the threshold and transition zones, respectively. The first has a luminous flux output $\phi=55800 \mathrm{~lm}$, whereas the second, for the transition, has a lower output $\phi=31334 \mathrm{~lm}$. Both have an estimated efficiency $\eta=137 \mathrm{~lm} / \mathrm{W}$.

- $\mathrm{CO}_{2}$ factor in Spain (National average 2017): $0.31 \mathrm{~kg} / \mathrm{kWh}$ [36].

- Cost per industrial kWh in Spain: $0.083 €$ [37].

A first set of actions consisting on forestation of portal surroundings with common ivy (hedera helix) [21,22], change from HPS to LED [26,27] and pavement with higher reflectance $[23,25]$ were considered. Their impact is shown in Table 4. 
Table 4. Main parameters of lighting installation impact after basic actions for energy savings are implemented.

\begin{tabular}{ccccccc}
\hline & $\begin{array}{c}\text { Luminance } \\
\left(\mathbf{c d} / \mathbf{m}^{\mathbf{2}}\right)\end{array}$ & $\begin{array}{c}\text { Length } \\
(\mathbf{m})\end{array}$ & $\begin{array}{c}\text { Nr. LED } \\
\text { Projectors }\end{array}$ & $\begin{array}{c}\text { Yearly cons. } \\
(\mathbf{M W h})\end{array}$ & $\begin{array}{c}\text { Yearly } \mathbf{C O}_{2} \\
\text { Emissions } \\
(\mathbf{t n})\end{array}$ & $\begin{array}{c}\text { Yearly Costs } \\
(\boldsymbol{€})\end{array}$ \\
\hline $\begin{array}{c}\text { Threshold } \\
\text { zone-1 } \\
\text { Threshold } \\
\text { zone-2 }\end{array}$ & 203.2 & 79.5 & 98 & 70.1 & 21.7 & 5817 \\
$\begin{array}{c}\text { Threshold } \\
\text { zone-3 }\end{array}$ & 172.7 & 39.8 & 42 & 29.8 & 9.2 & 2475 \\
$\begin{array}{c}\text { Transition } \\
\text { zone-1 } \\
\text { Transition } \\
\text { zone-3 }\end{array}$ & 142.2 & 39.8 & 34 & 24.5 & 7.6 & 2038 \\
$\begin{array}{c}\text { Transition } \\
\text { zone-3 }\end{array}$ & 61.3 & 184.7 & 118 & 56.9 & 17.7 & 4726 \\
Total & 40.6 & 184.7 & 58 & 42.7 & 13.2 & 3546 \\
\hline
\end{tabular}

These calculations were carried out departing from the following parameters:

$-v_{\max }=100 \mathrm{~km} / \mathrm{h}$

- Pavement reflectance: $\rho=0.35$

- Light sources in threshold zone: LED projector with luminous flux $\Phi=21,700 \mathrm{~lm}, \eta=111 \mathrm{~lm} / \mathrm{W}$.

- Light sources in transition zone: LED projector with luminous flux $\Phi=17,000 \mathrm{~lm}, \eta=127 \mathrm{~lm} / \mathrm{W}$.

- $\mathrm{CO}_{2}$ factor in Spain (National average 2017): $0.31 \mathrm{~kg} / \mathrm{kWh}$ [36].

- Cost per industrial kWh in Spain: $0.083 €$ [37].

In Tables 3 and 4, some parameters like the $\mathrm{CO}_{2}$ factor and the cost per industrial $\mathrm{kWh}$ are the ones used in Spain. This is because the model tunnel is located in Spain. Anyhow, the adaptation to the different national parameters must be kept on mind during the design phase of each specific tunnel.

The choice of common ivy is due to three of its main characteristics related to the objectives of this research: It is a perennial species, which avoids the formation of a dangerous sliding layer made of fallen leaves and mud in the tunnel portal; it is flexible enough to cover and adapt to the shape of the tunnel; and its reflectance is the lowest among several species tested in the literature [21,22]. Furthermore, its hydrological and climatological needs are wide enough to get adapted to a vast variety of geographical locations.

In addition to this configuration of the lighting installation, now the reduction of the maximum speed allowed inside the tunnel is going to be considered. This strategy has not been previously reported as a complementary and fully integrated measure.

As explained above, the reason the maximum speed decrease leads to such savings is multiple. On one hand, this speed is directly related with the safety distance (SD), as shown by Equation (1). This means that any change in the maximum speed allowed in one tunnel implies a change in SD: For a maximum speed of $100 \mathrm{~km} / \mathrm{h}, \mathrm{SD}=159 \mathrm{~m}$, whereas $v_{\max }=80 \mathrm{~km} / \mathrm{h}$ yields $\mathrm{SD}=98.4 \mathrm{~m}$. The impact of this relationship is due to the division of tunnels in different zones according to the lighting requirements, which establishes the length of main zones as a function of SD [1].

The length of the opencast zone immediately before the tunnel, called the "access zone", is SD established for wet pavements. The first and most energy-consuming zone inside the tunnel, the "threshold zone", has the same length, whereas the length of zone immediately after ("transition zone") does not depend on SD, but on $v_{\max }$ itself (distance run at $v_{\max }$ during $20 \mathrm{~s}$ ).

Since the threshold and transition zones consume most of the energy from the lighting installation, making them shorter by diminishing $v_{\max }$, and adapting the lighting installation to this new speed, will remarkably decrease the energy consumed, number of projectors and emissions. 
For a typical tunnel like the one considered, the luminance due to the reflection of sunlight on the portal surroundings is $\mathrm{L} 20=4168 \mathrm{~cd} / \mathrm{m}^{2}$. According to Table 2, a reduction in $v_{\max }$ from $100 \mathrm{~km} / \mathrm{h}$ to $80 \mathrm{~km} / \mathrm{h}$ means a reduction in $\mathrm{L}_{\text {th }}$ from $333.4 \mathrm{~cd} / \mathrm{m}^{2}$ to $250.1 \mathrm{~cd} / \mathrm{m}^{2}$.

As shown in Table 2, since the luminance in the transition zone depends on $\mathrm{L}_{\mathrm{th}}$, and, according to Equations (1) and (3), $\mathrm{L}_{\text {th }}$ depends on $v_{\max }$, it is clear again that its decrease also helps to reduce the energy consumed in this zone as well as the required number of projectors.

The reduction in $v_{\max }$ has been applied to the model tunnel together with other measures like portal surroundings forestation, change by brighter pavements, and change from HPS projectors to LED. Table 5 below shows the parameters of the lighting installation when a reduction from $100 \mathrm{~km} / \mathrm{h}$ to $v_{\max }=80 \mathrm{~km} / \mathrm{h}$ is introduced.

Table 5. Main parameters of lighting installation impact when maximum speed reduction is added to the actions in Table 4.

\begin{tabular}{ccccccc}
\hline & $\begin{array}{c}\text { Luminance } \\
\left(\mathbf{c d} / \mathbf{m}^{\mathbf{2}}\right)\end{array}$ & $\begin{array}{c}\text { Length } \\
(\mathbf{m})\end{array}$ & $\begin{array}{c}\text { Nr. LED } \\
\text { Projectors }\end{array}$ & $\begin{array}{c}\text { Energy Cons. } \\
(\mathbf{M W h} / \text { year) }\end{array}$ & $\begin{array}{c}\mathbf{C O}_{2} \text { Emission } \\
\text { (tn/year) }\end{array}$ & $\begin{array}{c}\text { Costs } \\
\text { (EUR/Year) }\end{array}$ \\
\hline $\begin{array}{c}\text { Threshold } \\
\text { zone-1 }\end{array}$ & 152.4 & 49.3 & 46 & 32.6 & 10.1 & 2705 \\
$\begin{array}{c}\text { Threshold } \\
\text { zone-2 }\end{array}$ & 129.5 & 24.6 & 20 & 13.8 & 4.3 & 1147 \\
$\begin{array}{c}\text { Threshold } \\
\text { zone-3 }\end{array}$ & 106.7 & 24.6 & 16 & 11.4 & 3.5 & 945 \\
$\begin{array}{c}\text { Transition } \\
\text { zone-1 }\end{array}$ & 61.0 & 148.0 & 70 & 34.2 & 10.6 & 2840 \\
$\begin{array}{c}\text { Transition } \\
\text { zone-3 }\end{array}$ & 45.8 & 148.0 & 54 & 25.7 & 8.0 & 2131 \\
$\begin{array}{c}\text { Transition } \\
\text { zone-3 }\end{array}$ & 30.5 & 148.0 & 36 & 17.1 & 5.3 & 1418 \\
Total & & 542.5 & 242 & 134.8 & 41.8 & 11,187 \\
\hline
\end{tabular}

The comparison of the main parameters of the lighting installation and the financial, energy, and environmental impact before and after the actions is clearly positive, as shown in Table 6.

Table 6. Comparison of lighting installation parameters with no action, actions on pavement, portal surroundings and LED projectors, and these actions combined with maximum speed reduction and impact.

\begin{tabular}{cccccc}
\hline & $\begin{array}{c}\text { Length Most } \\
\text { Energy-Consuming } \\
\text { Zones (m) }\end{array}$ & $\begin{array}{c}\text { Number } \\
\text { Projectors }\end{array}$ & $\begin{array}{c}\text { Energy Cons. } \\
\text { (MWh/Year) }\end{array}$ & $\begin{array}{c}\mathrm{CO}_{2} \\
\text { Emission } \\
\text { (tn/Year) }\end{array}$ & $\begin{array}{c}\text { Costs } \\
\text { (EUR/Year) }\end{array}$ \\
\hline $\begin{array}{c}\text { No action } \\
\text { Actions } \\
\text { pavement, }\end{array}$ & 714.6 & 516 & 535.9 & 166.2 & 44,488 \\
$\begin{array}{c}\text { surroundings } \\
\text { and projectors } \\
\text { Actions } \\
\text { pavement, }\end{array}$ & 714.6 & 438 & 252.5 & 78.3 & 20,961 \\
$\begin{array}{c}\text { surroundings, } \\
\text { projectors and } \\
\text { vmax }\end{array}$ & 542.5 & 242 & 134.8 & 41.8 & 11,187 \\
\hline
\end{tabular}

Table 7 below compares the relative savings among all the potential actions on the tunnel: Doing nothing, just changing HPS and pavement reflectance, and this last together with maximum speed decrease. 
Table 7. Savings achieved with the actions introduced in this work with respect to the previous, where only basic savings actions were considered. All values expressed in \%.

\begin{tabular}{cccccc}
\hline & $\begin{array}{c}\text { Length Most } \\
\text { Energy-Consuming } \\
\text { Zones }\end{array}$ & $\begin{array}{c}\text { Number of } \\
\text { Projectors }\end{array}$ & $\begin{array}{c}\text { Yearly Energy } \\
\text { Consumption }\end{array}$ & $\begin{array}{c}\text { Yearly } \mathrm{CO}_{2} \\
\text { Emissions }\end{array}$ & $\begin{array}{c}\text { Yearly } \\
\text { Costs (€) }\end{array}$ \\
\hline $\begin{array}{c}\text { Pavement, surr. and } \\
\text { LED vs. no action } \\
\text { All actions vs. } \\
\text { no action }\end{array}$ & 0 & 15.1 & 52.9 & 52.9 & 52.9 \\
$\begin{array}{c}\text { All actions vs. } \\
\text { pavement, } \\
\text { surroundings and } \\
\text { LED only }\end{array}$ & 27.8 & 53.1 & 74.8 & 74.8 & 74.8 \\
\hline
\end{tabular}

Although in Table 7, the figures concerning the number of projectors could seem strange, it is necessary to remark that before any action, the projectors used were high-pressure sodium (HPS), whereas after the basic actions and the decrease in maximum speed introduced in this work, all the projectors use LED technology.

The results presented in this section clearly show the profit of combining $v_{\max }$ reduction with other strategies to enhance tunnel sustainability. This profit is even higher in the special case of not very high mountains, where the shorter SD can avoid the inclusion of sky portions in the L20 cone: As shown in Figure 1, sky is included in the L20 cone basis. If its radius were smaller, sky would be out of the cone, which would have enclosed only the mountain, with lower reflectance. Since sky inside the cone remarkably raises the $\mathrm{L} 20$ luminance [1], as a result, $\mathrm{L}_{\mathrm{th}}, \mathrm{L}_{\mathrm{tr}}$, and the number of projectors in the whole tunnel also rise.

\section{Discussion}

The results presented in this research demonstrate that the adaptation of traffic regulations to decrease the maximum speed allowed in the access zone and whole interior of road tunnels, $v_{\max }$, can become a powerful strategy to make them much more sustainable. Given the particularities of these infrastructures, with a deep impact on financial, energetic, and material means, the proposal presented seems really reasonable in addition to the potential importance in terms of safety.

Indeed, independently from the energy savings and $\mathrm{CO}_{2}$ emissions reduction, the lower severity of accidents in tunnels, whose closed structure is an additional danger, resulting from a speed reduction, results in a higher road safety. This means an incalculable added value due to the saving in human lives, injuries, and economic impact. In this sense, the potential reduction in the reduction of $\mathrm{NO}_{\mathrm{x}}$ gasses is also a plus in terms of health improvement.

On the other hand, lower maximum speeds mean smaller L20 cones for the lighting demands calculations. Thus, the probability of enclosing a portion of sky, the main contributor to L20 value, remarkably decreases, especially in tunnels under not very high mountains (Figure 1).

Of course, speed reduction is not applicable to every tunnel due to potential traffic jams. This fact will demand long-term agreements at a political level in order to avoid irrational use or misuse of this measure. Hence, urban and peri-urban tunnels with very high traffic flow are not suitable candidates, whereas highway and many inter-urban tunnels with not very high average daily traffic are ideal for introducing these reductions.

Departing from these arguments and the results in previous sections, important conclusions can be deduced, whilst the study of new and challenging lines of work arises in a natural way from the open points that still remain. All these are presented in the next section.

\section{Conclusions}

In addition to the necessary actions to be taken from the side of the regulatory bodies and national administrations dealing with traffic management, the considerations above lead to several important conclusions supported by the results presented in this work. 
(1) Decreasing the maximum speed in road tunnels allows a decrease in the required luminance in the threshold and transition zones through a lower coefficient " $\mathrm{k}$ " and potential exclusion of sky in the L20 cone. These facts are very important because the major part of the energy is consumed in these zones.

(2) This decrease also results in a remarkably shorter length on threshold and transition zones. Given that the vast majority of the projectors are located in these sections of the tunnel, the reduction in their number is very high, with a consequent saving in materials use (cooper, aluminum, lamps, ballasts, control devices, etc.), recycling expenses and maintenance.

(3) The recycling of lighting devices is a recurrent problem due to some particularities related to the hazardous materials in both discharge lamps and LED. Thus, fewer projectors mean less recycling and an additional chance for a circular economy based lighting policy.

(4) The dangerous and costly maintenance of tunnels lighting installations requires traffic cuts or very risky operations involving many workers, traffic police, and annulment of one road lane for hours with the consequent impact on traffic flow. The impact of installations with fewer projectors on operation times, workers safety, and traffic flux is evident and must be considered when designing maintenance planning.

(5) In addition to the remarkable savings related to the installation itself, the decrease in the emissions of the vehicles due to a lower speed must also be very high and should be considered as an additional pro.

(6) The reduction of the maximum speed and the subsequent redesign of the installation, are fully compatible and creates a strong synergy with other actions to decrease the energy demands and the consumption in tunnels. This positive impact should be considered in every project or tunnel renewal.

In spite of these positive conclusions, more research on this matter is necessary in order to approach as much as possible to almost-zero consumption tunnels. One key factor in this approach is the improvement in the exactitude of certain calculations and the consequent data. Hence, the variations in the results depending on the $\mathrm{CO}_{2}$ factors from one country to another must always be considered during the design phase. Due to this fact, the results from one tunnel in one country can be quite different for the same tunnel in a different country.

Anyhow, the results presented make road tunnels more sustainable. Future research will consider the introduction of these measures within a more general framework, including traffic safety, effects on traffic flow, and other factors of great interest for other areas. In addition, effects of lower vehicle emissions on the requirements of the ventilation systems should also be a matter of interest for research in this specific field.

Author Contributions: Formal analysis, A.P.-G., F.S., and I.G.; Funding acquisition, A.P.-G.; Investigation, A.P.-G., F.S. and I.G.; Methodology, A.P.-G., F.S. and I.G.; Project administration, A.P.-G.; Writing-original draft, A.P.-G., F.S. and I.G.; Writing-review and editing, A.P.-G., F.S. and I.G..

Funding: This work was supported by the Spanish Ministry of Economy and Competitiveness as part of the Research Project ENE2015-67031-R (MINECO/FEDER).

Conflicts of Interest: The authors declare no conflict of interest.

\section{References}

1. Commision Internationale de l'Éclairage (CIE). Guide for the Lighting of Road Tunnels and Underpasses; CIE Publ: Vienna, Austria, 2004; Volume 88.

2. Gil-Martín, L.M.; Peña-García, A.; Jiménez, A.; Hernández-Montes, E. Study of Light-pipes for the use of sunlight in road tunnels: From a scale model to real tunnels. Tunn. Undergr. Space Technol. 2014, 41, 82-87. [CrossRef]

3. Qin, X.; Zhang, X.; Qi, S.; Han, H. Design of Solar Optical Fiber Lighting System for Enhanced Lighting in Highway Tunnel Threshold Zone: A Case Study of Huashuyan Tunnel in China. Int. J. Photoenergy 2015, 2015. [CrossRef] 
4. Peña-García, A.; Gil-Martín, L.M.; Hernández-Montes, E. Use of sunlight in road tunnels: An approach to the improvement of light-pipes' efficacy through heliostats. Tunn. Undergr. Space Technol. 2016, 60, 135-140. [CrossRef]

5. Wachenfelt Hv Vakouli, V.; Pacheco-Diéguez, A.; Gentile, N.; Dubois, M.C.; Jeppsson, K.H. Lighting Energy Saving with Light Pipe in Farm Animal Production. J. Daylight. 2015, 2, 21-31. [CrossRef]

6. Pacheco-Diéguez, A.; Gentile, N.; Wachenfelt, H.V.; Duboisba, M.C. Daylight Utilization with Light Pipe in Farm Animal Production: A Simulation Approach. J. Daylight. 2016, 3, 1. [CrossRef]

7. Spacek, A.D.; MotaNeto, J.; DagostinBiléssimo, L.; Ando Junior, O.H.; De FreitasNeto, G.P.; Da Silva Giansella, R.; Ferreira de Santana, M.V.; De FragaMalfatti, C. Proposal for an Experimental Methodology for Evaluation of Natural Lighting Systems Applied in Buildings. Energies 2017, 10, 1014. [CrossRef]

8. Spacek, A.D.; Mota Neto, J.; Dagostin Biléssimo, L.; Ando Junior, O.H.; Ferreira de Santana, M.V.; De Fraga Malfatti, C. Proposal of the Tubular Daylight System Using Acrylonitrile Butadiene Styrene (ABS) Metalized with Aluminum for Reflective Tube Structure. Energies 2018, 11, 199. [CrossRef]

9. Song, J.; Luo, G.; Li, L.; Tong, K.; Yang, Y.; Zhao, J. Application of heliostat in interior sunlight illumination for large buildings. Renew. Energy 2018, 121, 19-27. [CrossRef]

10. Gil-Martín, L.M.; Peña-García, A.; Hernández-Montes, E.; Espín-Estrella, A. Tension structures: A way towards sustainable lighting in road tunnels. Tunn. Undergr. Space Technol. 2011, 26, 223-227. [CrossRef]

11. Peña-García, A.; Escribano, R.; Gil-Martín, L.M.; Espín-Estrella, A. Computational optimization of semi-transparent tension structures for the use of solar light in road tunnels. Tunn. Undergr. Space Technol. 2012, 32, 127-131. [CrossRef]

12. Peña-García, A.; Gil-Martín, L.M. Study of pergolas for energy savings in road tunnels. Comparison with tension structures. Tunn. Undergr. Space Technol. 2013, 35, 172-177. [CrossRef]

13. Gil-Martín, L.M.; Gómez-Guzmán, A.; Peña-García, A. Use of diffusers materials to improve the homogeneity of sunlight under pergolas installed in road tunnels portals for energy savings. Tunn. Undergr. Space Technol. 2015, 48, 123-128. [CrossRef]

14. Abdul Salam, A.O.; Mezher, K.A. Energy Saving in Tunnels Lighting using Shading Structures. In Proceedings of the 2014 International Renewable and Sustainable Energy Conference (IRSEC), Ouarzazate, Morocco, 17-19 October 2014; pp. 519-524.

15. Wang, B.L.; Ye, Y.; Yan, B. Experimental Research on Application of the Natural Light to Tunnel Lighting Engineering. J. Light Vis. Environ. 2015, 39, 43-51. [CrossRef]

16. Drakou, D.; Burattini, C.; Bisegna, F.; Gugliermetti, F. Study of a daylight "filter" zone in tunnels. In Proceedings of the IEEE 15th International Conference on Environment and Electrical Engineering (EEEIC), Piscataway, NJ, USA, 10-13 June 2015; pp. 649-652.

17. Drakou, D.; Celucci, L.; Burattini, C.; Nardecchia, F.; Gugliermetti, F. Study for optimizing the daylight "filter" in a pre-tunnel structure. Study for optimizing the daylight "filter" in a pre-tunnel structure. In Proceedings of the IEEE 16th International Conference on Environment and Electrical Engineering (EEEIC), Florence, Italy, 7-10 June 2016; p. 4.

18. Drakou, D.; Burattini, C.; Mangione, A.; Bisegna, F. Exploring the daylight simulation of filter panels in a pre-tunnel structure. In Proceedings of the 2017 IEEE International Conference on Environment and Electrical Engineering and 2017 IEEE Industrial and Commercial Power Systems Europe (EEEIC/I\&CPS Europe), Milan, Italy, 6-9 June 2017; pp. 1-5.

19. Cantisani, G.; D'Andrea, A.; Moretti, L. Natural lighting of road pre-tunnels: A methodology to assess the luminance on the pavement-Part, I. Tunn. Undergr. Space Technol. 2018, 73, 37-47. [CrossRef]

20. Cantisani, G.; D'Andrea, A.; Moretti, L. Natural lighting of road pre-tunnels: A methodology to assess the luminance on the pavement-Part II. Tunn. Undergr. Space Technol. 2018, 73, 170-178. [CrossRef]

21. López, J.C.; Grindlay, A.L.; Carpio, M.C.; Peña-García, A. Strategies for the Optimization of Binomial Energy Saving Landscape Integration in Road Tunnels, WIT Transactions on Ecology and the Environment; WIT Press: Southampton, UK; Boston, MA, USA, 2014; Volume 190, pp. 511-520.

22. García-Trenas, T.; López, J.C.; Peña-García, A. Proposal to forest Alpine tunnels surroundings to enhance energy savings from the lighting installations. Towards a standard procedure. Tunn. Undergr. Space Technol. 2018, 78, 1-7. [CrossRef]

23. Moretti, L.; Mandrone, V.; D'Andrea, A.; Caro, S. Comparative "from cradle to gate" Life Cycle Assessments of Hot Mix Asphalt (HMA) Materials. Sustainability 2017, 9, 400. [CrossRef] 
24. Moretti, L.; Caro, S. Critical analysis of the Life Cycle Assessment of the Italian Cement Industry. J. Clean. Prod. 2017, 152, 198-210. [CrossRef]

25. Moretti, L.; Cantisani, G.; Mascio, P.D. Management of road tunnels: Construction, maintenance and lighting costs. Tunn. Undergr. Space Technol. 2016, 51, 84-89. [CrossRef]

26. Salata, F.; Golasi, I.; Poliziani, A.; Futia, A.; de LietoVollaro, E.; Coppi, M.; de LietoVollaro, A. Management Optimization of the Luminous Flux Regulation of a Lighting System in Road Tunnels. A First Approach to the Exertion of Predictive Control Systems. Sustainability 2016, 8, 1092. [CrossRef]

27. Wang, X.; Zhou, J. The application of stepless intelligent control system to LED illuminating brightness in city tunnel. Transp. Sci. Technol. 2009, 1, 92-94.

28. Salata, F.; Golasi, I.; Peña-García, A. Financial and environmental impact of combined actions in road tunnels for the decrease of energy and raw materials consumption. In WIT Transactions on Ecology and the Environment; WIT Press: Southampton, UK; Boston, MA, USA, 2018; Volume 215.

29. Liu, L.; Chen, R.C. A novel passenger flow prediction model using deep learning methods. Transp. Res. Part C Emerg. Technol. 2017, 84, 74-91. [CrossRef]

30. Wagenaar, J.; Kroon, L.; Fragkos, I. Rolling stock rescheduling in passenger railway transportation using dead-heading trips and adjusted passenger demand. Transp. Res. Part B Methodol. 2017, 101, 140-161. [CrossRef]

31. Dulebenets, M.A. A comprehensive multi-objective optimization model for the vessel scheduling problem in liner shipping. Int. J. Prod. Econ. 2018, 196, 293-318. [CrossRef]

32. Dulebenets, M.A.; Ozguven, E.E.; Moses, R. The Highway Beautification Act: Towards improving efficiency of the Federal Outdoor Advertising Control Program. Transp. Res. Part A Policy Pract. 2018, 110, 88-106. [CrossRef]

33. Jalalian, M.; Gholami, S.; Ramezanian, R. Analyzing the trade-off between CO2 emissions and passenger service level in the airline industry: Mathematical modeling and constructive heuristic. J. Clean. Prod. 2019, 206, 251-266. [CrossRef]

34. De Fomento, M. OC 36/2015 Sobre Criterios a Aplicar en la Iluminación de Carreteras a Cielo Abierto y Túneles; Tomo II: Recomendaciones Para la Iluminación de Túneles (OC 36/2015 on Criteria to be Applied in the Lighting of Opencast Roads and Tunnels; Volume II: Recommendations for the Lighting of Tunnels); Government of Spain: Madrid, Spain, 2015.

35. López, J.C.; Peña-García, A. Determination of lighting and energy demands of road tunnels using vehicle based photographs of the portal gates: An accessible and safe tool for tunnel renewal and maintenance. Tunn. Undergr. Space Technol. 2018, 78, 8-15. [CrossRef]

36. National Commission on Markets and Competition (CNMC) of Spain. Available online: http://gdo.cnmc. es/CNE/resumenGdo.do? (accessed on 3 February 2019).

37. Government of Spain. Ministry of Industry, Trade and Tourism. 2018. Available online: http:/ /www.mincotur.gob. es/es-ES/IndicadoresyEstadisticas/DatosEstadisticos/IV.\%20Energ\%C3\%ADa\%20y\%20emisiones/IV_12.pdf (accessed on 3 February 2019).

(c) 2019 by the authors. Licensee MDPI, Basel, Switzerland. This article is an open access article distributed under the terms and conditions of the Creative Commons Attribution (CC BY) license (http:/ / creativecommons.org/licenses/by/4.0/). 